\title{
Experimental and Numerical Study on Breaker Types of Solitary Waves over Arbitrary Bottom
}

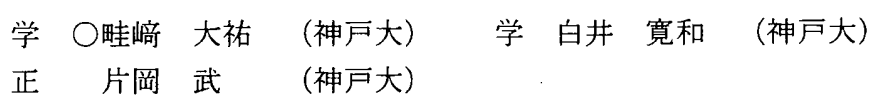

Daisuke Unesaki, Kobe University, 1-1, Rokkodai, Nada, Kobe, Hyogo

Hirokazu Shirai, Kobe University

Takeshi Kataoka, Kobe University

\section{1. 緒 言}

砕波は, 波形の変形過程により、「波峰の頂点前部が泡立ち 始め, それが次第に波進行方向に広がりながら崩れる Spilling (崩れ波型)」,「波の前面勾配が後面に比べて急になり, 波面 前部を巻き込むように砕けながら波進行方向に崩れる Plunging (巻き波型)」,「波頂点は崩れずに, 前面部の低い位 置から現れる頂点（2次波峰）が崩れる Collapsing（巻き寄せ 波型)」,「下部のほうから小さな砕波を次々に起こしながら傾 斜海岸を遡上する Surging（砕け寄せ波型）」の 4 種類の砕波 型に分類される ${ }^{1)}$.

本研究では, 底面地形の違いにより孤立波の砕波形状が異 なる要因を，水槽実験および数値シミュレーションによって 調べた。

\section{2. 水槽実験}

水槽は内径で高さ $0.2 \mathrm{~m}$ ，長さ $3 \mathrm{~m}$ ，幅 $0.05 \mathrm{~m}$ のアクリル製 である，底面地形はメラミンスポンジを用いて模型を作製し た。作動流体は水である。孤立波は，水槽の内側と同形（長 方形）に模った造波板を水平方向に平行移動させることによ って手動で発生させた。そしてその波が砕波に至るまでの波 形を撮影した。またPIVによる流速測定も行った。

実験のパラメータは先端角 $\left.\theta=10,900^{\circ}\right)$ とステップ高さ $d=1,2,3,4,4.5(\mathrm{~cm})$, および入射波の最大波高 $\eta_{\text {max }}$ である（図 1 参照)。ただし，水深 $D$ は $0.05 \mathrm{~m}$ である.

\section{3. 数值シミュレーション}

一様な重力加速度が働く系において, 表面張力を無視した 自由表面を持つ密度一定な非圧縮性完全流体の渦なし運動を 考える. 支配方程式は速度ポテンシャルに対するラプラス方 程式であり, 境界条件は水面上の運動学的条件と力学的条件, および底面で突き抜ける流れがない条件である，また，全て の変数は重力加速度, 水の初期位置深さによって無次元化す る.ここで原点が平均水面にある $x-y$ 直交座標を導入する と，孤立波は次の形の解で表される.

$$
\phi=\Phi_{s}(x-c t, y), \quad \eta=\eta_{s}(x-c t)
$$

ただし, $c$ は孤立波の伝播速度であり, $\Phi_{s}$ の空間微分と $\eta s$ は $x \rightarrow \pm \infty$ で減衰する. 数值計算法としては, 過去の水面波 の数值計算において広く利用され, その有効性が確認されて いる境界要素法（BEM）を用いた ${ }^{2)}$. 計算パラメータは $\eta_{\text {max }}$ $=($ 最大波高 $) /($ 水深 $)(=0.1,0.3,0.5,0.7), \theta\left(=10,30,45,60,70^{\circ}\right)$, およびd (=0.1 0.9) である (図1参照).

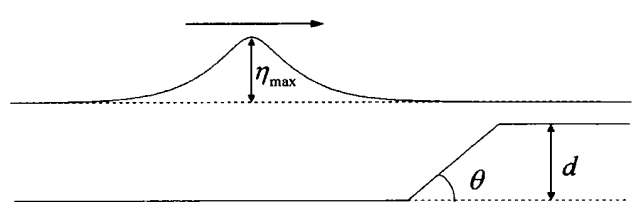

Fig.1 Geometry

\section{4. 結果および考察}

(1) 砕波形状の分類および傾向

$\eta_{\max }$ または $d$ が大きくなるほど砕波型は Spilling $\rightarrow$ Plunging $\rightarrow$ Collapsing の順に変化していく傾向が分かった．ただし $\theta=10^{\circ}$ の場合には Collapsing には至らない(図 2 参照).
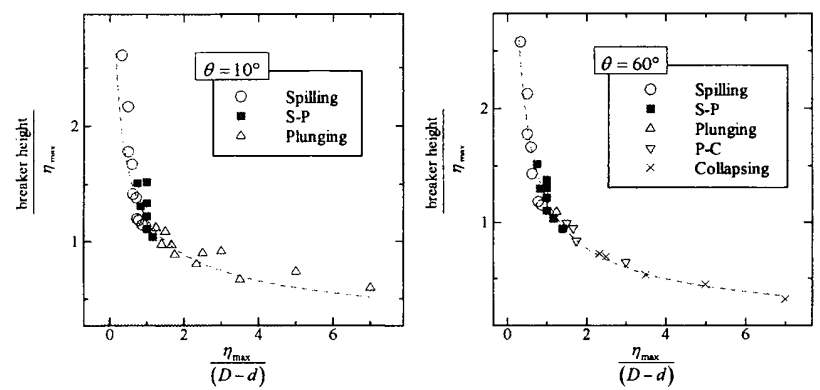

Fig.2 Breaker types distribution as functions of $\eta_{\max }$ and $d$. (2) 流速分布

それぞれの砕波型について流速分布を調べた結果, Spilling および Plunging は水深の減少（非線形性の卓越）による波の 突っ立ちが, Collapsing はステップ底面の角を回る強い流れが その砕波型に主な影響を及ぼしていると考えられる.

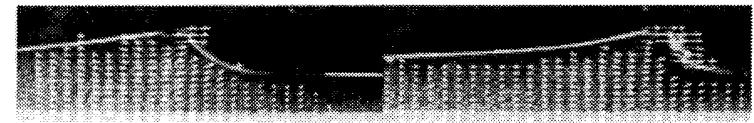

Fig.3 Flow velocity distribution of Spilling breaker by PIV.

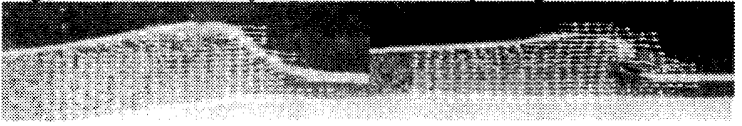

Fig.4 Flow velocity distribution of Plunging breaker by PIV.

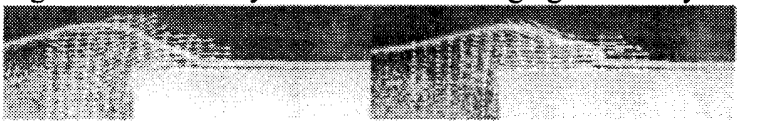

Fig.5 Flow velocity distribution of Collapsing breaker by PIV.

\section{文献}

1) Galvin C. J., Breaker Type Classification on Three Laboratory Beaches, (1968), J. Geophys. Res. Vol.73, No.12, pp. 3651-3659.

2) Tanaka M., Dold J. W., Lewy M. and Peregrine D. H., Instability and breaking of a solitary wave,(1987),J. Fluid Mech.,Vol.185, pp.235-248. 